\title{
$\mathrm{T} \mathrm{HE}$
}

\section{Journal of the American Medical Association.}

EDITED FOR THE ASSOCIATION BYN. S. DAVIS.

PUBLISHED WEEKLY.

\section{ORIGINAL ARTICLES. \\ DIPHTHERIA IN THE CITY OF KALAMAZOO, MICHIGAN, IN 1884.}

Chicago, February 27, is86.

No. 9.

\author{
BV II. B. HEMENWAY, A.M., M.D., \\ I.ATH HKAIITH UEHCER OY KAT.AMA\%OO.
}

T'o the physician three fields of work present themselves, in which he may spend his time and strength. He may devote himself to the study of the normal and morbid conditions of the human system, simply for the satisfaction received in learning; he may direct his attention to the cure of diseased bodies; or, his thought may be occupied in discovering and making known the cause of sickness.

l'here is, perlaps, no other one disease about which there is so much disagreement among doctors, as diphtheria. It is not my intention here to discuss especially the identity or non-identity of diphtheria, and membranous croup. Neither do I propose to look for those minute forms of life, which one sees so clearly, and another observer says do not exist, save in the mind of the enthusiast. Nor shall I ask the reader to investigate with me, at present, whether we shoukl give to the patient brandy or quinine, turpentine or calomel, ice in the throat or hot applications. I shall endeavor to give facts as they were, uncolored by any pet theory or idea. When an opinion is stated I shall seek to so express it that the reader will at once be able to separate the true from the possibly false.

During the latter part of the year 1884 , there occurred in the city of Kalamazoo, Michigan, a large number of cases of diphtheria. At first they seemed to be to a degree sporadic. Though in some localities several persons were ill, yet no connection could be found between the disease in one section and that in another. Before proceeding, however, to give a history of the epidemic, perhaps a general view of the city would not be unprofitable.

Kalamazoo is a beautiful little city of about I 5,000 inhabitants, located in the midst of a rich farming region. It nestles in a hollow, with hills nearly surrounding it. The river, from which the place took its name, runs into the city from the east, twice turns back upon its course and then runs northward until beyond the limits of the corporation. 'Though hills have been mentioned, there is no marked elevation of the earth's surface. The river flows silently, and the wind may easily sweep any street in town. 'Two creeks join the river within the city walls. $A t$ the "Ox-bow" an old settler cut a canal across a narrow neck of land, and located a tlour-mill, using his canal for a race. He needed no pond as the river fumishes all the power needed without any special storiure of the water. Just south of the city the stream is divided. A portion flows on in its natural channel; the remainder is conducted along higher land to run another mill. before it gets to this mill the rave expands into a storage pond. Along this larger creck, and around the "Ox-bow" of the river, the land is low, and in the springtime it is often covered with water. North of the city the valley spreads out to the width of three-quarters of a mile. 'The soil of most of this low land is a rich alluvium. Mixed with the mould is more or less sand, and an occisional bowlder is to be seen. Here, too, are peat beds, which furnish a good grade of that fuel. The centre of the eity is luilt upon higher ground, which, like the surrounding hills, is composed hurgely of sand. In some places $\mathrm{so} \mathrm{much}$ clay is mixed with the sand that the earth is very firm. In others, the sand may be found in a pure state. Under the whole city, from six to twenty five feet below the surfice, there is a bed of clay. This is not very thick in any place, though its thickness varies greatly. At the paper-mill, a short distance south of the city, an attempt has been made to get an artesian well. 'The drill went down between 750 and 760 feet below the surface. For about 200 feet the workmen bored through all kinds of drift material, mingled sand, gravel, clay, and bowlders. At that depth a small stream was struck, but it did not How with sufficient force to answer the purpose. The water had a decided taste and smell of coal oil. A little more than 200 feet from the surface shale was reached. As far as the drill went below that point nothing but shale was found, and at last the enterprise was abandloned.

A study of the geology of this section of the State shows that Kalamazoo is situated nearly in the centre of a large depression in the rock. 'This basin, about seventy-five miles in diameter, and nearly round, is filled, as has already been mentioned, with gravel, sand, and other drift material. Reference to the cut may aid the reader to understand the elements of the water supply of the city. 'This figure is of course schematic, and drawn without reference to proportion, as the ratio of the diameter of the basin to the depth of the same is many times greater than one might infer from the diagram. Imagine, then, AA to represent the bed rock, and $M M$ the surface of 
the ground. $\mathrm{BCl}$ would then represent the drift material. The water level would be practically the same (DDD) for the whole basin, with an outlet (at E) in the Kalamazoo river. At the depth of $C$ there would be little to produce motion in the water; it would be without special current. More water, therefore, coming into the basin in the form of rain or sewage would, as soon as it reached the water level, tend to flow out towards $\mathrm{E}$. Theoretically, therefore, and actual tests show it to be a fact, the water at the water level would not be as pure as that from a greater $\mathrm{dep}_{\mathrm{t}} \mathrm{th}$. There are three sources or modes of water supply for the citizens: Open, or dug wells, drive wells, and the city pumping works. This last water is commonly known by the name of the first pumps used at the works-Holly. The source of this water pumped by the city engines is a deep well (figure, F), on low land, and here they settle where most people would not think of locating their houses. All around on the flats one may see their little huts and cottages. Some of these are kept as clean as any house could be; many are less wholesome, and some are decidedly filthy. They are decided fatalists. When the attention of a mother was called to the filthy water drank, as the cause of her child's diphtheria, she replied, "No water! It comes from Himmel." 'Their children are put to work almost as soon as they can walk. 'The soil where they live is well fitted for celery raising. The shipping season lasts about six months. To give a little idea of the amount of that article raised one need only state that it is not an unusual thing to ship forty or more tons of celery in a single day; sending it to the Atlantic and Pacific Oceans and to the Gulf of Mexico. The women

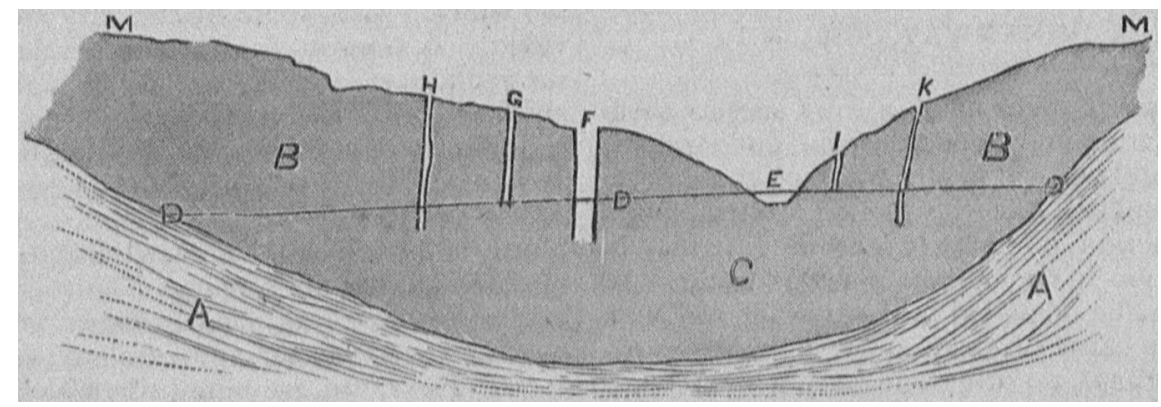

so constructed that the water only enters from the and children do much of the washing and preparing bottom. Among the dug wells I included what for shipment. They will often stand all day with many call spring water. For example, in case $3_{30}$, their hands in cold water at this labor. In more than to get drinking water a barrel was sunk in the ground one instance children have been sent out to this work by the side of a ditch. Strange to say, at the level before they were entirely well.

of the water in the ditch the aqueous fluid was to be Kalamazoo is not a very unhealthy place. The found in the barrel. 'To make the work as easy as estimated number of deaths for the year $188_{4}-85$ possible, the point selected for lowering the barrel was about $122 / 3$ per thousand. Omitting the deaths. was where the surface came nearest to the water from diphtheria and other so-called preventable clislevel. The water to be had from wells on the hill in the northwest corner of the city is purely surface water, as it comes from above the clay stratum already mentioned. Many of the drive wells do not go down deep enough to gain the advantage of drive wells, as they only give surface water.

The present system of sewage was adopted in December, 1880. The first sewers put down were laid the next summer. Juring the summer of 1884 the work of laying the lateral sewers was pushed vigorously, and at the close of the season about twelve miles of pipe had been laid. In I 885 the work was again pushed forward. The system adopted is essentially that of Col. Waring. Only a very small per centage of the residences had been connected with the public sewers at the time of the outbreak of diphtheria. The Arcadia creek, which flows through the centre of the city, was an open sewer. An ordinance was passed during the year forbidding its use as such. In the older portion of the city the ground is full of cesspools, many of them long since forgotten.

There is a large Dutch population in the city. In their native country they were accustomed to live eases, the rate would have been 8 per sooo. In I884, from the 7 th day of May to the 21 st of June, there was no grave opened in the Protestant portion of the city cemetery; and from May 26th to June 21 st there was no interment in the whole cemetery. In June, 1885 , there were only ten burials in the city.

We are now prepared to study the earlier cases of the epidemic, and then study the outbreak as a whole. Case 1.-F., aged 3 years, only child. Parents both deaf mutes. Family live on the upper floor of a frame house. The Arcadia creek, above mentioned, flows through the back yard. 'The creek is higher than the cellar floor. The little girl was reported ill with scarlatina about the last of April. As health officer I visited the place and confirmed the diagnosis. Ordered the father, who was a mechanic employed in a furniture factory, to remain at home. I ordered them to keep the child as perfectly isolated as possible. The house was in a good condition generally. The cellar was damp, and the mother informed me that, a day or two before, the baby played down cellar for some time. She attributed her sickness to that. She was quite sure the child 
had not played with other children. A few days later, on April 29, the attending physician reported that the scarlatinal symptoms had nearly left, but that he had a clear case of diphtheria just developed that day. There had been no known case of diphtheria in the city for several months. 'The family could not conceive of any means by which they might have come in contact with that disease. The case progressed favorably and in two weeks was reported recovered; but on May 20 the doctor was sent for in haste, and when he reached the house the child was dead, probably from cardiac paralysis. 'The family used water from a dug well, and there was no sewage for the house. A baby under one year old in the same house did not get sick.

Cases 2, 3, and 4.-F., F., and $\mathrm{M}$., aged $10,4 \frac{1}{2}$, and 2 , living about six blocks from case $\mathrm{t}$, all came down with diphtheria on July 20 . The house inside was in good sanitary condition. The sink-pipe emptied upon the surface of the ground near the house, and the filthy water stood there until absorbed by the ground. Six feet from where the water struck the earth a drive well entered the ground. A microscopical examination of the water from this well showed large cquantities of organic matter. A former occupant of the house "could not live in Kalama\%o on account of her health." On July 25 the mother of these children was taken with diphtheria. The use of the well water was. stopped, and all except case 3 , which died of septicamia, recovered. I could not trace these cases to a previous case.

Cases 6 and 7 lived just around the corner from the preceding, and had played with them before they were taken sick. They were taken sick on July 26 and 30 respectively. Case $6, F$, aged 8 years, lived in an old house, which sat down on the ground, without cellar wall, and which showed marked signs of decay. Both these families used dug wells, and neither place had sewage.

Case 8.-Colored, M., aged I 2 years, was taken sick August 1st. I.ived in an old house without sewage. Used dug well. Could not trace this to any preceding case.

Case 9.-M., is years old, lived in the south-eastern portion of the city. (The others were all north of Main street.) Could not trace the case to preceding cases. House near marsh land, and no ventilation under the rooms where he lived. Taken sick August 5. Died August 24 of cardiac paralysis.

Case 10.-M., aged 3, taken sick August i6th, and

Case 11.-F, aged 7, taken sick August i 7 th, lived in the north-eastern portion of the city in an old house without other foundation than the earth. A hole in the ground was called a cellar, and there the winter's wood was kept, and the bark and sawdust accumulated. Could not trace to other cases.

Cases 12 to 17 , inclusive, were colored children, in two houses, and though I could not trace them to case 8 , yet they may have taken the clisease from him. The sanitary condition of their homes was very poor. 'Three of these cases died.

Cas: 18.-M., i 2 years old, was taken sick september 28 . He had always been sickly. The family lived on the third floor of a tobacco store.
Holly water and city sewage. Traps imperfect; alley in the rear not in good condition. Died suddenly from rupture of an abscess in the pharynx. Could not trace to previous case.

Case 19.-Could not be traced to previous cases. Used water from dug well. Sewage of place nil. House old and decaying.

Case 20.-Mild case. lived in second story of a store building. Private drain; Holly water; private alley in rear in very bad condition just before the boy was taken sick; slops were thrown out into that alley by neighbors and allowed to stand upon the ground until dried up.

Of the next two cases I simply recorded "bad surroundings." 'Though I could find no communication with case.19, yet they may have taken the disease from him. More likely they might have all three taken the disease from case 25 , though I think they did not do so.

Cases 23 to 25 , inclusize, and 35, ages $5,21 / 2,9$, and 7 ; sex, F., F., M., M.; taken sick September $18,18,15$, and 22 . The house was a small frame structure of one story. The cellar walls were made of two layers of boards, between which sawdust was packed. In the spring the cellar floor was covered with water. No attempt had been made to ventilate the place. 'The sawdust was molly and mushy. In the cellar were the remains of vegetables not less than a year old. 'The boards around the door-way were quite rotten. 'There was no provision for the care of slops, but the tidy housewife stepped upon the back porch and threw her dishwater, etc., upon the surface of the ground. The dug well had partially caved in, on account of the giving away of its wooden walls, and consequently the surface of the ground sloped towards the well. The water from the well was used for cooking and drinking. All the children in this house were sick. The boys, who were away from home more or less, were but slightly affected. The girls, who had been in the house much, were very sick, and the older one died. Next door to this family lived another, whose sink-pipe opened upon the surface of the ground among a lot of weeds. From the street both of these places looked very neat and clean. I examined the weeds and found that the ground was a soft slime several inches deep. 'l'here was a window over these weeds about five feet from the ground. By this window a child slept. She had diphtheria. The family used al dug well under the house.

Not to be burdensome I will only make a few more selections.

In Case to the drinking water used was very bad. Cases $55,56,58,59,60, \mathrm{~F} ., \mathrm{M} ., \mathrm{l} ., \mathrm{l} ., \mathrm{l}$, aged 3 years, is months, 12,14 and 15 years. First three fiatal. Taken sick (October $6,8,6$, I, and 2 , respectively. The three older children were sent ont peddling vegetables after they were taken sick. No physician was called until the night before the first child died. Upon examination I found a dug well close by the back door. The kitchen had no floor but the ground. On two sides of this kitchen was a ditch, eight inches deep, which served to receive and hold the family slops. It did not conduct them away. 
When I reached the house this ditch was full of black water. The well was not six feet from this ditch, and yet the mother wondered that the health officer would not allow her a couple of weeks before having that ditch filled up.

In another house upon the marsh, with ditches around, and those ditches dammed to help the celery, there were four children, the oldest i I years old, and the youngest 18 months. All died except the baby. 'The baby was not sick. In this case a dug well was used, and I found the women standing upon the well platform pouring their slops off from its edge.

In Case 163 a young lady fell into the fire and was very seriously burned. One of the attending surgeons was at that time attending a case of diphtheria. The general sanitary condition of tho house was good.

In one house, old and without sewage, dug well, and no cellar or chance to ventilate under the house, there werc eleven cases and seven deaths.

Cirse 215.-A beautiful little cottage was built on ground that had been used for a long time as a clairy. man's cow yard. A well was dug not more than fifteen feet from the privy. Soon after the family moved into the cottage the little girl was taken sick.

In a few cases I could find nothing about the premises in a bad sanitary condition. "That, however, was no proof that the disease might not have arisen from filth. The physician reporting case 69 recorded as the source of contagion "unknown." The patient was a butcher, $3^{6}$ years old. His children were playing with him and even kissing him after the disease was clearly defined, and yet he was the only member of the family attacked. 'The neighbors had complained of his barn-yard, but the health officer did not think it probable that Mr. $\mathrm{F}$. had taken the disease there. Examination of the meat market showed that right under where Mr. F. stood at his work, there was a water-closet in the cellar. The sewer-pipe was broken and leaked both water and gas. In another instance (from my own practice) a family liverl in a new brick block of four houses. liverything seemed to be in good condition until I asked the owner about the sewer-traps. I thenfound the following condition: There was a large and good cesspool of brick behind the house, and only twenty feet from the building. There was an opening at the surface of the ground for ventilation and cleaning. Four lead pipes connected this cesspool with the four kitchen sinks. 'There were no traps, but the pipes were as straight as possible. The pipe to No. 3 was the shortest and straightest. Since the upper end of the pipe was several feet higher than the outof-doors ventilator of the cesspool, very naturally in kitchen No. 3 there was frejuently to be detected an odor of sewer gas. In this house, all three children had diphtheria without being exposed to any previous case so far as known. Traps were at once put into each sink-pipe. No other children in the block had the disease.

In most families where the first cases were promptly isolated other persons were not attacked.

Table I gives a synopsis of the water supply and sewage of the first 292 cases. I may here express a regret that I did not keep a fuller account of all the cases. Whoever has attempted, however, to keep statistics of this kind readily realizes how difficult it is to get accurate information, and how often the statistician receives an intimation that the information sought is none of his business.

TABLE I.

WATER SUPPIY AND SEWAGF.

\begin{tabular}{|c|c|c|c|c|c|}
\hline \multirow[b]{2}{*}{ 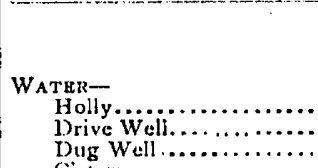 } & \multicolumn{2}{|c|}{ "TOTAL. } & \multicolumn{2}{|c|}{ l'A'TAL. } & \multirow[b]{2}{*}{$\begin{array}{c}\text { Percent } \\
\text { of Cases } \\
\text { latal. } \\
24.53 \\
9.90 \\
28.47 \\
\ldots \ldots\end{array}$} \\
\hline & $\begin{array}{c}\text { Num- } \\
\text { ber. } \\
53 \\
101 \\
137 \\
1\end{array}$ & $\begin{array}{r}\text { Per- } \\
\text { cent. } \\
\times 8 \\
35 \\
47 \\
4\end{array}$ & $\begin{array}{c}\text { Num- } \\
\text { ber, } \\
13 \\
10 \\
39 \\
\cdots\end{array}$ & $\begin{array}{l}\text { Per- } \\
\text { cent. } \\
21 \\
16 \\
63 \\
\cdots\end{array}$ & \\
\hline $\begin{array}{l}\text { WAGli- } \\
\text { Cessi } \\
\text { City } \\
\text { NoS } \\
\text { othI.. }\end{array}$ & $\begin{array}{r}33 \\
6 \\
253 \\
292\end{array}$ & $\begin{array}{r}11 \\
2 \\
87 \\
100\end{array}$ & $\begin{array}{r}5 \\
2 \\
55 \\
62\end{array}$ & $\begin{array}{r}89 \\
100\end{array}$ & \\
\hline
\end{tabular}

About twenty-five per cent. of the entire population of the city use the Holly water. Since only eighteen per cent. of the diphtheria patients used that water, it seems to indicate that they are less likely to take the disease on that account. Probably there are other reasons besides the kind of water drank why these citizens should be less prone to the disease. A very large proportion of the cases occurred among the poor population, especially among the Dutch.

In regard to the portion relating to scwage, it must be noticed that the places where no provision had been made for the care of kitchen slops are decidedly the most prolific of cases, and fatal cases. The very small number of cases in which the premises are connected with the city sewers renders the last columr of that line of little value. One of the two fatal cases was No. I63, already mentioned, in which the injuries received nearly took the patient's life, before the diphtheria attacked her. As relating to the subject of sewage, it may be noticed that no cases occurred upon the east side of the river until the dams on the river were fixed, and the water raised enough to overflow some low land there. After that there were nineteen cases, six of which were fatal.

After a careful study of the epictemic, I came to the following conclusions:

I. Diphtheria is essentially a filth disease.

2. It may be produced without any relation to a former case.

3. During the earlier stages it is but feebly contagious.

4. A simple "sore throat," including under this head tonsillitis, pharyngitis and laryngitis, may develop into diphtheria, without receiving contagion from a previous case.

5. Diphtheria, after being once produced, may become contagious and epidemic.

6. Diphtheria and the proneness to the disease may be modified by the constitution of the person, and by atmospheric conditions.

7. Diphtheria and membranous croup are the same disease.

To what extent loes one attack protect from future attacks? I regret to say that I have no accurate data on this subiect. Some persons were at tacked a 
second time. On the other hand, in one family of having been severely burned. The man 33 years old four children all but one had the disease some years had pneumonia. His four children had diphtheria, ago. 'This year this one had it and died.' 'Those who had had it before escaped this year.

What relation has age and sex to the disease? Table II gives the number of cases of males and females of each age from April 15,1884 , to July I, 1885. For study the cases are divided into four groups: 'Those under 6 years old; those from 6 to Io inclusive; those from I 1 to 5 inclusive, and those over I5. It will be noticed that almost ninety-two per cent. of the males, eighty-five per cent. of the females, and eighty-eight per cent. of all cases were under $\mathrm{I} 6$ years old.

TABLEL II.

NUMBER OF CASLS.

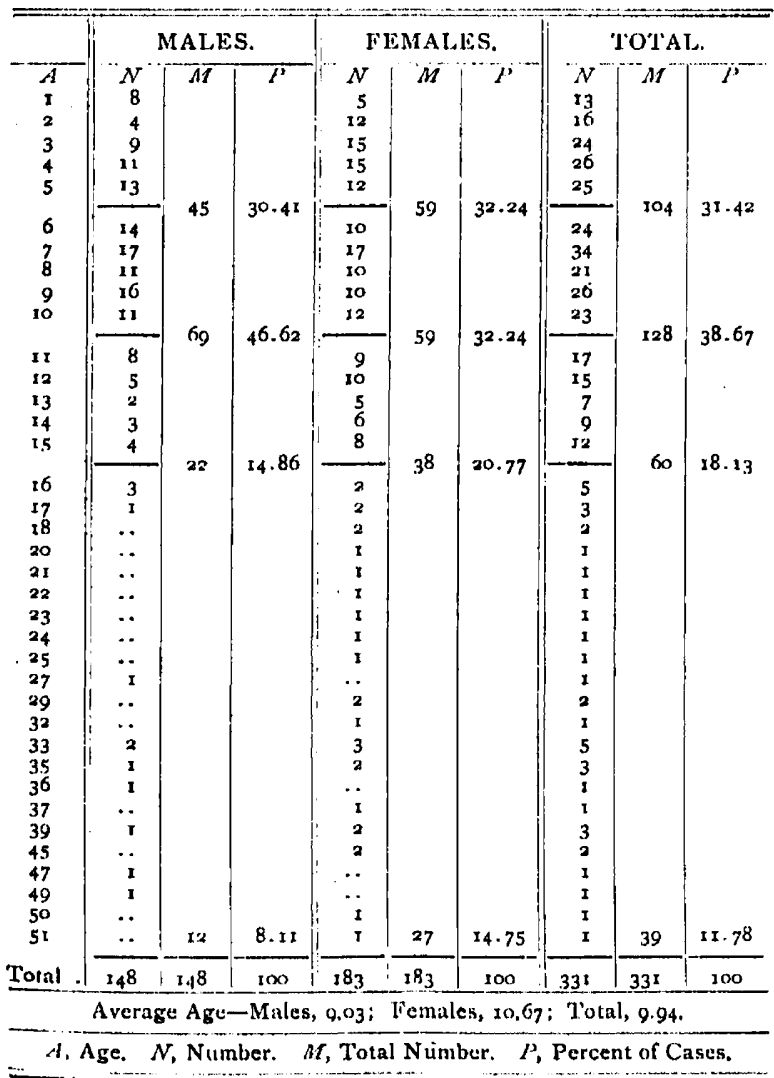

Table III shows that ninety-three per cent. of the males, ninety-five per cent. of the females, ninetyfour per cent. of all cases proving fatal were under 16 years of age. Of the cases over 23 years old, all but four occurred in families where there had been previous cases among the children. Among the four is the butcher mentioned as Case 60. One was an old colured woman who had not had any child sick with it so far as known, but she lived in the neighborhood of cases among the negroes. Of the fatal cases over 15 years old, the boy of I6 was an unusually well developed lad. . The girl of 17 was also well developed. So far as could be seen there was no special reason why they shonld either of them die. The girl of 18 was the one already twice referred to as and three of them died. After the last death he caught cold, and at the same time diphtheria took hold of him, almost immediately extending through his entire lungs. It will also be noticed that more girls than boys were attacked during the first period. In the next the boys are most numerous. During the years when the maidens are preparing for womanhood they are again more likely to be troubled by the disease.

In the first year of life there were 13 cases-8 males and 5 females; at 2 year's there were 16 cases-4 males and 12 females; at 3 years there were 24 cases - 9 males and 15 females; at 4 years 26 cases-1 I males and 15 females; at 5 years 25 cases- 13 males and 12 females; at 6 years 24 cases- 14 males and ro females; at 7 years 34 cases, equally divided; at 8 there were 21 cases - I 1 males and ro females; at 9 there were 26 cases- 16 males and ro females; 23 cases in the roth year included I 1 males and $12 \mathrm{fe}$ males; 77 cases at i 1 were divided among 8 males and 9 females; 15 cases at 12 included 5 males and Io females; 7 cases at 13 included 2 males and 5 females; 9 cases at 14 showed 3 males and 6 females; 12 cases at 15 give 4 males and 8 females; 5 at 16 give 3 males and 2 females; 3 at 17 show 1 male and 2 females; and at. 8 there were 2 cases, both females.

The age at which death took place in the fatal cases was as follows: At $x$ year 3 males and 1 female; at 2, 6 females; at 3 years 4 males and 4 females; 4 males and 7 females at 4 years; 2 males and 4 females at $5 ; 4$ males and $\mathrm{I}$ female at $6 ; 1$ male and $3 \mathrm{fe}$ males at $7 ; 2$ males and 4 females at $8 ; 1$ each at 9 ; 2 females at 10 ; 1 each at 11 ; 1 male and 2 females at $12 ; 2$ females at 13 ; one each at $14 ; 1$ male and 2 females at $15 ; 1$ male at $16 ; 1$ female at 17 ; and 1 female at 18.

TABLE III.

lATAI, CASES

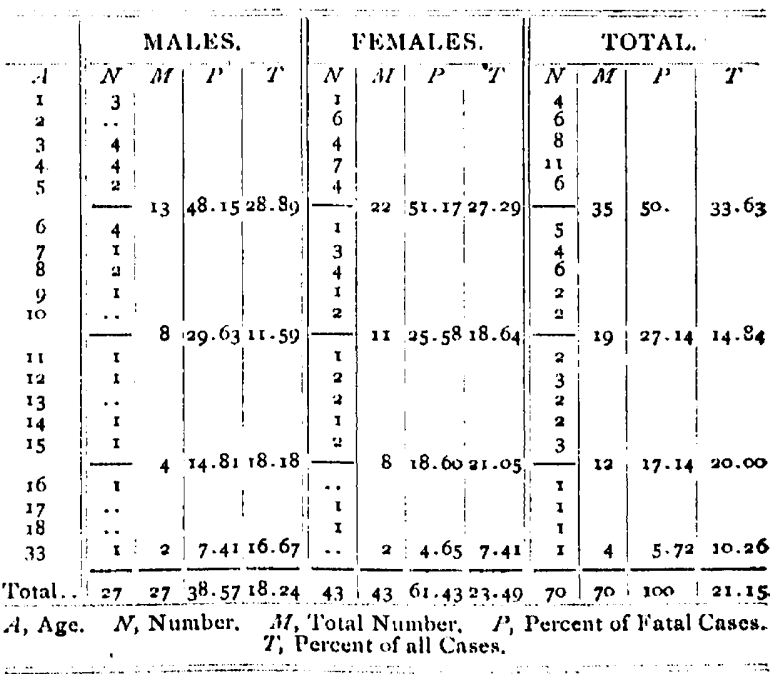

It will be noticed that 7 seems to be the favorite age for patients. It will also be noticed that boys reached their highest mortality for any age at the 
years 3,4 and 6 , losing four at each of those ages. The girls lost seven at the age of 4. Table III shows that the mortality of females was greater than that of males. What is the influence of weather upon diphtheria? Table IV gives the weather report, and number of new cases of diphtheria each week for the last six months of 1884 . I often noticed that when the amount of ozone dropped to one or two for two or three days, new cases would be reported, and old ones were likely to be worse. $\Lambda \mathrm{t}$ Christmas time there was considerable snow upon the ground, and there were but two or three cases of diphtheria. The snow melted quite suddenly during the next few days, and within two weeks there were twenty-five new cases reported. When the ground had been frozen a short time the number of cases was small.

TABLE IV.

\begin{tabular}{|c|c|c|c|c|c|c|c|c|}
\hline \multicolumn{2}{|c|}{ Week ending } & Cases!: & Har. & Ther. & Wind. & C'loud. & Ozone. & Rain. \\
\hline July (Sraction) & 5 & . & 29.091 & 70.25 & 3.85 & 5.08 & $2, \infty$ & 0.22 \\
\hline & 12 & $\ldots$ & 29.175 & 68.14 & 5,00 & 6.05 & 2.14 & 0.16 \\
\hline & 39 & .. & 29. 199 & 64.65 & 5.04 & 4.06 & 1,57 & 0.07 \\
\hline & 26 & 5 & 29.215 & 72.78 & 5.06 & 6.00 & 2.05 & I. $7^{8}$ \\
\hline August....... & 2 & 3 & 29.117 & $7^{2.43}$ & 5.00 & 7.00 & 2.00 & 0.26 \\
\hline & 9 & $\mathbf{I}$ & 29.257 & 60.57 & 5.00 & 7.06 & 2,06 & 0,33 \\
\hline & 16 & I & $39.3^{66}$ & 72.53 & 4.00 & 4.00 & 1.06 & 0.12 \\
\hline & 23 & $\mathbf{1}$ & 29.278 & 72.31 & $6 . m$ & 4.00 & 2,00 & 0.52 \\
\hline & $3^{\circ}$ & 3 & 29. 108 & 64.89 & $5 \circ 3$ & 7.06 & 2.06 & 0.76 \\
\hline September.... & 6 & 3 & 29.292 & 72.78 & 4.06 & 5.00 & 1.05 & $\cdots$ \\
\hline & 13 & I & 29) $37^{6}$ & 70,22 & 5.03 & 4.02 & 1.08 & 0,48 \\
\hline & 20 & 9 & 29.365 & 63.43 & 6.08 & 4.03 & 1.07 & 0.18 \\
\hline & 27 & $y$ & 29.216 & 04.00 & 6.03 & 7.00 & 2.05 & 1.54 \\
\hline October...... & 4 & 15 & 29.266 & 68.24 & 5.01 & $8 . \infty$ & 2,02 & 0.24 \\
\hline & II & 27 & $29 \cdot 3^{81}$ & $59 \cdot 76$ & 6.02 & 5.00 & 2.00 & 0.96 \\
\hline & t8 & 46 & 219.399 & 5.5 .57 & 5.03 & 5.00 & 2.04 & 0.18 \\
\hline & 25 & 24 & 24.497 & 49.09 & 6.04 & 5.00 & 2.03 & $0.9^{8}$ \\
\hline November.... & I & 23 & $29 \cdot 3^{611}$ & 42.57 & $5 . \infty 0$ & 9.05 & 2,01 & 0.82 \\
\hline & 8 & 27 & 29.439 & $3^{8.48}$ & 5.02 & $6 . \infty 0$ & 2.07 & 0.85 \\
\hline & I5 & 27 & $29.3^{89}$ & 45.24 & 4.071 & 5.03 & 5,07 & $\cdots$ \\
\hline & 22 & 20 & $29 \cdot 316$ & $3^{6.76}$ & 5.09 & 7.00 & 3.00 & 0.12 \\
\hline & 29 & 15 & $2 t) .063$ & 27.62 & 6.06 & 10.00 & 3.00 & 0.87 \\
\hline December.... & 6 & 5 & 29.153 & 40,86 & $4.07 !$ & 7.00 & 3.06 & 0.83 \\
\hline & 13 & 4 & $29: 335$ & 31.33 & 7.01 & 9.00 & 1,09 & 1.02 \\
\hline & 20 & 2. & $29 \cdot 326$ & 13.81 & 5.02 & 9.04 & 2.07 & $1.9^{8}$ \\
\hline & 27 & $\mathrm{~J}$ & 29.379 & 75.33 & 5.05 & 9.03 & 3.04 & 1,34 \\
\hline (fraction) & 311 & 12 & 29.255 & $39 \cdot 75$ & 6.00 & $(1), \infty)$ & 3.02 & 2.05 \\
\hline
\end{tabular}

Table giving for ench week the number of new cases of tiphtheria in the city, the average barometric pressure, thermometer ( $F$.), velocity of wind, amount of cloud, wonc, and rainfall. (Cloud and wone marked on scale of 10.$)$

Of the fatal cases, the modes or causes of death were as follows:

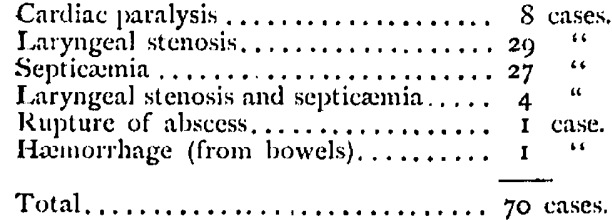

Su far as known, of the cases reported one had the membrane only in the larynx. Three or four females had the membranes over the genitals. Several had the memlrane upon abrasions of the skin. I think that, without exception, cases in which blisters had been raised progressed towards recovery more slowly, and were more liable to septicamia than those not so treated. In several cases the parents had applied kerosene oil to the neck externally, before the physician was called. At first, knowing that some good authorities had recommended that vesicants be used, I permitted my patients to be so treated, thougli I did not recommend it. but I became thoroughly convinced that the practice did much harm.

Though, as before stated, I do not propose to discuss the subject of therapeutics, yet it may not be out of place here to say that I think, with only one exception, all the physicians here use some preparation of mercury in the treatment of this disease. Some prefer as a general thing the iodides, others the chlorides. Especially in robust children, my own preference is for the mild chloride, given in 2-grain doses, every two or three hours until six powders have been taken for a child 5 years old. 'The one physician above mentioned depends largely upon whisky and quinine. His success certainly is not better than the average. Within the last year various papers have recommended the burning of tar and turpentine. I think those who have tried it here will not try it again. For laryngeal trouble, however, some have thought they were aided by the vapor of turpentine. I used it in one case with good results. The turpentine was put into boiling water, and the patient inhaled the steam. Noticing the tendency towards cardiac paralysis, from the first I gave all my cases digitalis, and after the fever began to subside I administered tr. nucis vomica. I cocally I used a solution of carbolic acid or permanganate of potassium. 'Though I did not try it, I think the mixture of solutions of corrosive sublimate and permanganate of potash would do good; better, indeed, than any other application I have seen suggested. Personally I am convinced that ice applications are detrimental, but I allow the patients to drink water freely. Alcohol is good, but it must be used with caution. I am convinced that we must study to prescribe such medicines as will not disgust the patients, as not infrequently serious results have followed the resistance of the patient against taking the drug prescribed.

'The patient's strength must be kept up, not by stimulants, but by food. When all else fails I depend on milk, given, if necessary, in dram doses every half hour. Since most of the cases occurred among the poor and more ignorant population, where they did not receive, and could not get. competent nursing, it was the opinion of the attending physicians that if we had had a city hospital where such patients could be cared for, from forty to fifty per cent. of the fatal cases would have been saved, and the whole number of cases would have been diminished.

In what proportion of the cases did paralytic symptoms develop? I could not tell exactly, as physicians made no report of paralysis except incicidentally. I knew, however, of a dozen cases out of the 33r. There probably were more. One of these was almost entirely paralyzed, and afterwards recovered. In two cases at least, the paralysis developed certainly a month after apparent recovery took place. One of these proved fatal.

I am under obligations to Mr. A. M. Munn, of the Michigan Asylum for the Insane, for kindly giving me free access to his weather record. The observations were made by $\mathrm{Mr}$. Munn at the Asylum, which is situated upon the hill in the southwest portion of the city.

Kalamazoo, January 10, IS86. 